\title{
BANYAK ALASAN MENGAPA PENDIDIKAN ITU PENTING
}

\section{Rof idatul Hasanah}

Judul : Banyak alasan mengapa pendidikan it u penting

Kalimat Topik : Banyak alasan mengapa pendidikan itu penting

Kalimat Pendukung :

1. Pengantar

a. Lat ar belakang Pendidikan

2. Agama

Kunci ut ama (what)

3. Pengalaman

Berbagai kegiat an (why)

4. Prof esional

Sikap yang tertanam (how)

5. Penut up

Rangkuman banyak alasan mengapa pendidikan it u penting 


\title{
BANYAK ALASAN MENGAPA PENDIDIKAN ITU PENTING
}

\section{Rof idatul Hasanah}

\author{
Program Studi Pendidikan Guru Sekolah Dasar \\ Fakult as Keguruan dan IImu Pendidikan \\ Univer sit as Nahdlatul Ulama Sidoarjo \\ Email: rof idatulhasanah.rh@gmail.com
}

Pendidikan merupakan salah satu sekt or penting dalam pembangunan di setiap negara. Menurut Undang- Undang No. 20 Tahun 2003 tent ang Sistem Pendidikan Nasional dalam pasal 1 disebutkan bahwa pendidikan merupakan usaha sadar dan terencana untuk memujudkan suasana belajar dan proses pembelajar an agar peserta didik secara akt if mengembangkan pot ensi dirinya unt uk memiliki kekuatan spiritual keagamaan, pengendalian diri, kepribadian, kecerdasan, akhlak mulia, serta keterampilan yang diperlukan dirinya, masyarakat, mengembangkan segala potensi yang dimiliki peserta didik melalui proses pembelajaran.

Keper cayaan adalah kunci ut ama dalam menjalankan suat u kehidupan, yang mana kehidupan sangat berkesinambungan dengan pendidikan. Pendidikan adalah segala usaha yang dilakukan unt uk mengembangkan pot ensi diri individu agar memiliki kemampuan pengendalian diri, berakhlaq mulia, kepribadian yang semakin baik, memiliki kecerdasan serta terampil. Pendidikan untuk apa? Pendidikan sebagai bekal dalam menjalani kehidupan sekarang, esok dan nanti. Pendidikan juga dapat menentukan pekerjaan seseorang. Pendidikan sangat ber per an penting dalam pembent ukan karakter 
manusia, agar manusia lebih bisa mengendalikan dirinya dengan baik. Pendidikan tidak hanya didapatkan di bangku sekolah, namun pendidikan ada dimana-mana, pendidikan tersebut dinamakan pendidikan non- $f$ ormal. Pendidikan non- $\mathrm{f}$ ormal bisa didapatkan di luar bangku sekolah dan bangku kuliah. Pendidikan juga ada didalam keluarga, lingkungan masyarakat dan diselur uh jagad alam ini. (Ahmad:2010)

Pendidikan akan mengajarkan pada manusia agar memperoleh pengalaman hidup. Pengalaman adalah bekal dalam melaksanakan suatu kegiatan agar apa yang dikerjakan berjalan baik sesuai koridor yang telah dit ent ukan. Begitu pula sebagai manusia didunia ini, manusia har us mempunyai banyak bekal dalam hidup, yakni pengalaman. Mengapa harus pengalaman? Karena dengan sebuah pengalaman seseorang akan bisa merasakan pembelajaran secara langsung dari tiap kegiatan-kegiatan yang telah dijalaninya. Pengalaman yang baik akan menjadikan semangat terus untuk maju kedepan, namun tidak menunt ut kemungkinan bahwa didalam semua itu pasti terdapat pengalaman pahit. Akan tetapi pengalaman pahit bukanlah sebuah hukuman bagi diri seseor ang, namun itulah pembelajar an agar individu ter sebut pant ang menyer ah dalam ber proses. (Ahmad:2010)

Sejak dilahirkan manusia membawa sebuah potensi dan harapan untuk berhasil dikemudian hari. Pendidikanlah yang menjadi jembatan penghubung individu dengan masa depannya. Akan tetapi manusia jarang menyadari potensi apa yang sebenarnya ia miliki. Bakat at au potensi yang telah dibawa sejak lahir itu perlu adanya sebuah pemupukan. Oleh karena itu untuk mengembangkan sebuah bakat yang dimiliki oleh individu ter sebut dibut uhkan adanya pendidikan. Pendidikan adalah hal yang sangat penting yang mempengaruhi kegiatan atau pekerjaan yang dilakukan oleh tiap individu, termasuk menjadikan individu terbekali dengan pentingnya sebuah prof esionalitas. Karena prof esionalitas akan menjadi tuntutan dalam dunia kerja. Sebanyak apapun potensi yang dimiliki individu, namun jika tidak disertai dengan sikap prof esional maka hasil yang ingin dicapai dapat dikat akan kurang mengena pada target yang telah dit ent ukan. (Suwandi:2017) 
Adapun komposisi pengangguran berdasarkan tingkat pendidikan sebagai berikut:

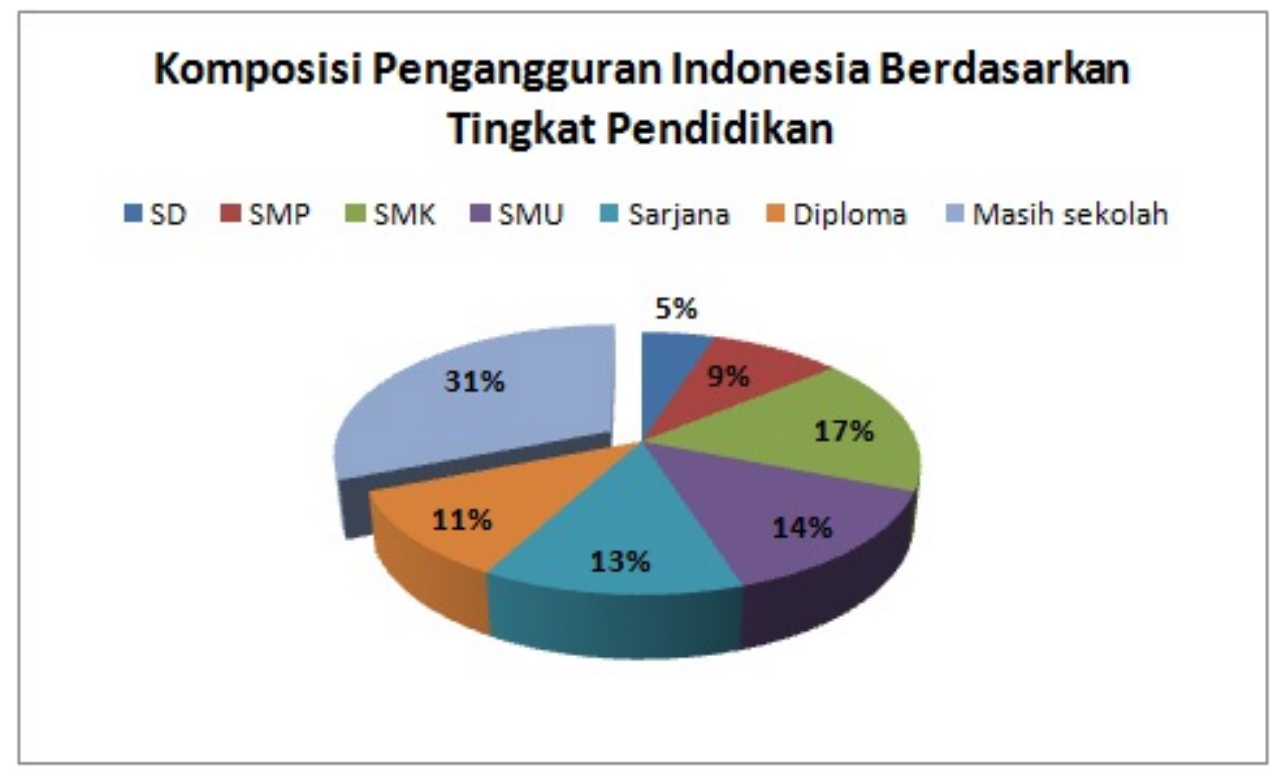

Gambar 1.1 Diagram komposisi penganggur an ber dasarkan tingkat

pendidikan

\section{Kesimpulan}

Pendidikan sangat dibutuhkan dalam perjalanan hidup manusia. Agar manusia dapat menentukan arah menuju tujuan hidupnya dengan terbekali oleh kepribadian yang baik, akhlaq yang mulia, kecerdasan, kemampuan mengendalikan diri, ter ampil, mendapatkan banyak pengalaman sert a memiliki sikap pr of esional.

\section{Daf tar Pustaka}

Nawawi, Ahmad. (2010). Pentingnya pendidikan nilai moral bagi generasi penerus: Jur usan PLB FIP Univer sit as Pendidikan Indonesia.

Suwandi \& Julianto. (2017). Penggunaan metode bermain peran dalam pembelajaran ppkn untuk meningkatkan aktivitas emosional siswa kelas VB SDN Put at Jaya III/379 Surabaya. Jurnal Penelitian: Vol 5, No 3. 
Undang- undang RI Nomor 20 tahun 2003. Sistem Pendidikan Nasional. Pasal 1. 